\title{
Effect of Demonstration on Adoption of Udder Health Management Practices by Dairy Women
}

\author{
Vaishali V. Banthiya, S. W. Sawarkar, S. P. Landge* and N. V. Khode \\ Department of Veterinary \& Animal Husbandry Extension, \\ Nagpur Veterinary College, Nagpur-6, India \\ *Corresponding author
}

\section{A B S T R A C T}

\section{Keywords}

Demonstration, Adoption, Udder health management practices and Dairy women

\section{Article Info}

Accepted:

05 June 2020

Available Online:

10 July 2020
Due to WTO challenges and importance of udder health in dairy economics, the present study was conducted with the objective to study effect of demonstration on adoption of udder health management practices. One hundred dairy women were randomly selected from purposively selected ten high milk producing villages around the Nagpur city of Maharashtra state in India. The data was recorded 'before' and 'after' the demonstration of ten major udder health management practices with the help of personal interview schedule method. The overall effect of demonstration of udder health management practices was significant on the adoption of these practices by the dairy women.

\section{Introduction}

India has emerged as the largest producer of milk with 20.17 percent share in total milk production in the world and also the largest population of milch animals in the world (APEDA, 2018). Inspite of this, our livestock farmers seems to missing out on the issues like quality milk production which would increase our share in export of dairy products. The non-adoption of udder health management practices might be because of their lack of practical exposure and awareness about global market and not knowing the importance of udder health status in dairy economics. Due to WTO challenges and global opportunities in marketing of milk, it is essential to improve the quality of milk at farmer's level.

In dairy economics, the economical losses can be prevented by maintaining the health of udder which may also effect on increasing milk production. Neha Rao and Patel (2001) practiced post milking teat dipping and calculated benefit cost and revealed that it 
would be saving a loss of Rs.9211. The value of a dairy cow in the final event depends only on the quantity of wholesome disease free milk she can produce (Ernest, 1980). Therefore to create global market opportunities and minimizing the economical losses in production, it is needed to demonstrate udder health management practices for dairy farmers at home or farm.

In dairy farming, udder health management is nothing but preventive measures for minimizing the bacterial population in the produced milk. Other practices associated with lower Somatic Cell Count in milk were the use of a freestall system, sand bedding, cleaning the calving pen after each calving, surveillance of dry-cow udders for mastitis, use of blanket dry-cow therapy, parenteral selenium supplementation, udder hair management, and frequent use of the California Mastitis Test (Dufour et al., 2011).

Among the communicational and educational technologies, demonstrations are the oldest, best and simplest tool for the transmitting sophisticated technology in a simple and understandable form. The use of producerowned demonstration farms and producer-led demonstrations creates a more relaxed, informal setting for the dissemination and evaluation of knowledge for progress and the ultimate transfer and application of the knowledge through such demonstrations (Scott, 1992).

Women contributes heavily in dairy farming activities with involvement in activities like cleaning of shed, milking, selling of milk, dung disposure and preparation of milk and milk products (Jadav and Durgga Rani, 2014). By keeping this view in mind the present work has been undertaken with the objective to study the effect of demonstration on adoption of udder health management practices by dairy women.

\section{Materials and Methods}

The present study was conducted in Nagpur district of Maharashtra state. The information regarding maximum milk supplying villages was collected from various milk procurement agencies involved in the daily supply and sale of milk to the Nagpur city. According to received information, ten high milk supplying villages around Nagpur city were purposively selected for the study. Out of ten, eight villages viz. Fetary, Old Borgaon, New Borgaon, Mahurzari, Chincholi, Bodhala, Godhani and Bokara were from Nagpur tahsil and remaining two villages viz. Kawatha and Mhasada were from Kamptee tahsil of Nagpur district. After selection of the villages, a list of dairy women from each of the selected villages was prepared. Keeping the sample size of only one women from each family ten women from each village were randomly selected to have a total sample size of one hundred dairy women. After going through available literature, ten major udder health management practices were identified in consultation with the experts for the demonstration. The interview schedule was pre-tested and finalized for Pre and Post demonstration data. Accordingly udder health management practices were studied in the first phase followed by demonstration of scientific udder health management practices. The adoption of newly demonstrated practices were studied after one month through personal interview method coupled with observations.

\section{Results and Discussion}

The results in the table showed that washing the udder with clean and lukewarm water before fifteen minutes of milking, sponging out the udder with clean and dry cloth after udder washing, washing and cleaning the dairy animal every day and teats dipping in potassium permanganate solution before and 
after milking was fund to be effective tools for demonstration of udder health management for the clean milk production. It is evident from the data presented in Table 1 that 'chi-square' value showed overall significant effect of demonstration on adoption of udder health management practices by dairy women. Whereas ' $z$ ' value within practices shows significant effect of demonstration on adoption of udder health management practices by dairy women regarding daily washing and cleaning of the animals; regular clipping of hairs around the udder and hindquarter; washing the udder with clean and lukewarm water fifteen minutes before milking; cleaning and drying of udder with cloth after washing; using separate cloth for probable diseased animal and dipping the teats in potassium permanganate solution before and after milking. The significant effect of demonstration found in terms of adoption of udder health management practices could be attributed to quality milk production as evident by the longer keeping quality of the milk. Galton et al., (1982) also demonstrated the use of pre milking teat preparation with iodine in pre- dipping.

Table.1 Effect of demonstration on adoption of udder health management practices by dairy women

\begin{tabular}{|c|c|c|c|c|c|}
\hline \multirow{2}{*}{$\begin{array}{l}\text { S. } \\
\text { No. }\end{array}$} & \multirow{2}{*}{$\begin{array}{l}\text { Udder health } \\
\text { management practices }\end{array}$} & \multicolumn{2}{|c|}{ Mean } & \multirow{2}{*}{ S.E. } & \multirow{2}{*}{$z$ value } \\
\hline & & Before & After & & \\
\hline 1. & $\begin{array}{l}\text { Provide ventilation for natural air } \\
\text { and sunlight in the animal shed }\end{array}$ & 0.10 & 0.10 & - & - \\
\hline 2. & $\begin{array}{l}\text { Put sand or saw dust in cold, damp } \\
\text { and marshy places of shed }\end{array}$ & 0.94 & 0.95 & 0.147 & 0.060 \\
\hline 3. & $\begin{array}{l}\text { Wash and clean the dairy animal } \\
\text { everyday }\end{array}$ & 0.83 & 0.96 & 0.394 & $0.333 * *$ \\
\hline 4. & $\begin{array}{l}\text { Regular clipping of hairs around } \\
\text { the udder and hindquarter of dairy } \\
\text { animal }\end{array}$ & 0.76 & 0.84 & 0.440 & $0.181 * *$ \\
\hline 5. & $\begin{array}{l}\text { Wash the udder with clean and } \\
\text { lukewarm water before fifteen } \\
\text { minutes of milking }\end{array}$ & 0.80 & 0.100 & 0.320 & $0.625 * *$ \\
\hline 6. & $\begin{array}{l}\text { Wipe out the udder with clean and } \\
\text { dry cloth after udder washing. }\end{array}$ & 0.13 & 0.56 & 0.736 & $0.589 * *$ \\
\hline 7. & $\begin{array}{l}\text { Use separate cloth to wipe of } \\
\text { udder of probable diseased dairy } \\
\text { animal }\end{array}$ & 0.11 & 0.16 & 0.268 & $0.186 * *$ \\
\hline 8. & $\begin{array}{l}\text { Dip the teats in potassium } \\
\text { permanganate solution before and } \\
\text { after milking }\end{array}$ & 0.04 & 0.23 & 0.599 & $0.317 * *$ \\
\hline 9. & Use full hand method in milking & 0.73 & 0.76 & 0.716 & 0.041 \\
\hline \multirow[t]{2}{*}{10.} & $\begin{array}{l}\text { Keep animal in standing position } \\
\text { at least for fifteen minutes after } \\
\text { milking }\end{array}$ & 0.99 & 0.100 & - & - \\
\hline & Chi square value & \multicolumn{4}{|c|}{$27.2 * *$} \\
\hline
\end{tabular}


The result showed that standard plate counts and coliform counts were significantly reduced in raw milk by 5 and 6 fold respectively as compared to other methods of pre milking udder preparations. These findings were also supported by Drendle et $a l$. , (1993) and Reneau (2004).

The present study states that demonstration has vital contribution in adoption process of animal husbandry. These findings of the study are also supported by Sohal et al., (1982) who reported significant effect of intensive extension education programme on adoption of udder cleaning before milking. In the present study the adoption of the scientific udder health managemental practices by the dairy women could be credited to the understanding of the importance of udder health care that lead to minimize production losses. The fact that these women were commercial farmers, their interest might have motivated them for adoption of udder health management practices so as to minimize the production losses caused by the incidences like mastitis.

The non-significant effect of demonstration is found on adoption of udder health management practices like providing ventilation for animals, use of full hand method in milking and to keep animal in standing position at least for fifteen minutes after milking. This non-significant effect might be due to less difference in 'before' and 'after' observations as the dairy women might be well aware about the principles behind the adoption of these practices. The nonsignificant effect of demonstration on adoption of full hand milking method might be due to sudden change in skills or routine habits in the style of milking.

The study concludes that the farm demonstration has vital role in adoption of udder health management practices.
The demonstrations should be organized frequently for necessary change in skills of dairy women. The study also highlighted the importance of the demonstrations in the adoption of scientific udder health managemental practices. The method demonstration may also be fruitful to change the skill of dairy women towards the adoption of full hand milking and an exclusive campaign can be planned for changing the milking style of the dairy women for improving the quality of milk.

\section{References}

Dhama O.P. and O.P. Bhatnagar. 1999 Education and communication for development. Oxford \& IBH Publication Pvt. Ltd. New Delhi.

Drendle, T.R., P.C. Hoffman, A.N. Bringe and T.Y. Syverud. 1993. The effect of pre-milking teat disinfection on somatic cell count and clinical mastitis. R359A, University of Wisconsin Madison, College of Agriculture and Life Sciences.

Dufour, S., Fréchette, A., Barkema, H. W. Mussell, A, and Scholl, D. T. (2011) Invited Review: Effect of Udder Health Management Practices on Herd Somatic Cell Count. J of Dairy Science. 94(2):563-79.

Jadav S. J. and V. Durgga Rani (2014) Participation of Farm Women in Rural Dairy Enterprise- A Review Trends in Biosciences 7(13): 1381-1384.

Neha R. and P.R. Patel. 2001. Cost effectiveness of control measures of sub clinical mastitis in Kankrej cows. Round Table conference, IAAVR, held at Nagpur: 51-56.

Palanisamy, M., N. Sriram Ramasamy and A. Selvalatha. 2003. Dairy farmer knowledge and adoption level of modern cattle management practices, Cheiron, 31 (1 and 2): 15-18. 
Reneau, J.K. 2004. Udder preparation for quality milk production at http://www.ansci.umn.edu.com.

Scott M. Barao. 1992. Behavioral Aspects of Technology Adoption. Journal of Extension, Vol.30 (2), www.joe.org
Shoal, T.S., J.N. Singh and J.P. Singh. 1982. Impact of Intensive Extension Education on the Adoption of Scientific Dairy Farming by Landless Rural Families around Karnal (Haryana). J.Of Dairy Sci., 35 (4) :447-453.

\section{How to cite this article:}

Vaishali V. Banthiya, S. W. Sawarkar, S. P. Landge and Khode. N. V. 2020. Effect of Demonstration on Adoption of Udder Health Management Practices by Dairy Women. Int.J.Curr.Microbiol.App.Sci. 9(07): 135-139. doi: https://doi.org/10.20546/ijcmas.2020.907.015 